\title{
Glioma の神経管外転移
}

\author{
田村 勝・川瀼 純一・深町 彰*・若尾 哲夫* \\ Extraneural Metastases of Gliomas
}

\author{
Masaru Tamura, Jun-ichi Kawafuchi, Akira Fukamachi* \\ and Tetsuo Wakao*
}

Department of Neurosurgery, Gunma University, Maebashi 371

* Devision of Neurosurgery, Yamanashi Prefectural Central Hospital

\begin{abstract}
Summary
Elcven cases of anaplastic gliomas with extraneural metastases are reported in this paper. All cases fulfilled Weiss' minimal criteria for confirmation of extraneural metastases of gliomas. The cases were analysed according to the mode of metastascs such as the blood stream, ventriculoperitoneal shunt and lymphogeneous spread.

The group of metastases via the blood stream included one case of cerebral ependymoblastoma, one anaplastic astrocytoma, one glioblastoma and two medulloblastomas. Main metastatic sitcs of organs were the liver in four cases, bone in three, and the lungs in two. Two cases of dural invasion by glioma tissue were confirmed by operation and autopsy. Venous invasion by tumor cells was verified histologically in one case of medulloblastoma. Blood stream metastases must be taken into consideration in cases of dural invasion and/or venous invasion by tumor tissue.

Two cases of metastases via a ventriculoperitoneal shunt were observed in cases of fourth ventricle ependymoblastoma and pontine glioblastoma. Marked leptomeningeal dissemination was recognized at autopsy in both cases. The case of ependymoblastoma with distinct peritoneal metastases showed ascites 22 months after the ventriculoperitoneal shunt. Two small peritoneal metastatic deposits were found in a case of pontine glioblastoma. Metastases by the shunting procedure might occur in cases of gliomas with leptomeningeal dissemination.

The group of lymphogeneous metastasis included three cases of anaplastic astrocytomas and one case of glioblastoma. All of these cases were operated on more than twice and bone flaps were removed in the first or the following operations. Three out of four cases showed massive extracranial encroachment of growth directly through the bony defect. Metastases to cervical lymph nodes on the craniotomy side was the first manifestation of this mode of metastasis.
\end{abstract}

Key words : glioma, neoplasm metastasis, cerebrospinal fluid shunts, lymphatic metastasis

\section{Iはじめに}

悪性神経勝腫の神経管外転移 は比㜞的稀である。 Smith $5^{16)}$ は Armed Forces Institut of Pathologyk㧍け る8,000例 $の$ 神経廖腫中35例に, Schuster $5^{14)}$ は1, 500例 の神経膠腫中7例に神経管外転移を認めた. Kretchmer ${ }^{8)}$
は1974年までに報告されているWeiss ${ }^{203}$ の criteria を满

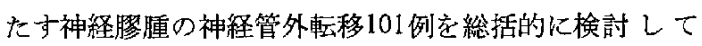
いる，最近では鹃迶液内誘導術による神経管外転移の報告 が增加してきている ${ }^{67715)}$. これら神経管外転移を生し た神経翏腫恃大部分 1 回以上の手術侵襲を受けており， 開頭術を受けずに神経管外転移を生ずることはきわめて

\footnotetext{
群馬大学脂神経外科

*山梨県立中央病院这神経外科

[連絡先：干371 前橋市昭和町3-39-22, 群馬大学脳神経外科, 田村 勝]

1980年1月8日 受稿
} 
Table 1 Extraneural metastases of gliomas via the blood stream

\begin{tabular}{|c|c|c|c|c|c|c|c|c|}
\hline Case & $\begin{array}{l}\text { Age } \\
\text { (years) }\end{array}$ & Sex & Type of tumor & Location & Operation & $\begin{array}{l}\text { Irradiation } \\
\text { (chemotherapy) }\end{array}$ & $\begin{array}{l}\text { Post-op. } \\
\text { survival } \\
\text { (months) }\end{array}$ & $\begin{array}{l}\text { Distant } \\
\text { metastases }\end{array}$ \\
\hline 1 & 22 & $\mathrm{~F}$ & $\begin{array}{l}\text { ependymo- } \\
\text { blastoma }\end{array}$ & 1. Frontal & 1 & $\begin{array}{c}\text { Linac X-ray } \\
9,600 \text { rads }\end{array}$ & 23 & lung, liver \\
\hline 2 & 33 & F & $\begin{array}{l}\text { anaplastic } \\
\text { astrocytoma }\end{array}$ & r. temporal & 1 & $\begin{array}{r}\text { Linac X-ray } \\
5,000 \text { rads }\end{array}$ & 3 & $\begin{array}{l}\text { lung, liver } \\
\text { vertebrae \& } \\
\text { fermur }\end{array}$ \\
\hline 3 & 33 & F & glioblastoma & cerebellum & 1 & $\begin{array}{l}\text { Linac X-ray } \\
2,600 \text { rads } \\
\text { vasoprcssin- } \\
\text { corticosteroid } \\
\text { therapy }\end{array}$ & 2 & liver \\
\hline 4 & 1 & M & medulloblastoma & cerebellum & —* & $\begin{array}{l}\text { Linac X-ray } \\
13,750 \text { rads }\end{array}$ & 14 & $\begin{array}{l}\text { liver, heart, } \\
\text { vertebrae, } \\
\text { pancreas, } \\
\text { capsule of } \\
\text { spleen \& } \\
\text { adipose tissuc } \\
\text { around adrenals }\end{array}$ \\
\hline 5 & 10 & M & medulloblastoma & cerebellum & 1 & $\begin{array}{r}\text { Linac X-ray } \\
4,000 \text { rads }\end{array}$ & 13 & $\begin{array}{l}\text { extensive bony } \\
\text { metastases }\end{array}$ \\
\hline
\end{tabular}

*VP shunt only performed

稀で, Anzil ${ }^{13} の$ 自験例含含めた 4 例の review とBrander

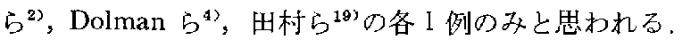

我々はこれまでに神释膠腫の神程管外転移例を 5 例報 告してきたが(15)17)18318，ここにその後の6 症例在扣え， 11剖检例につき，血行性，リンパ行性，髄液内誘導術に よる shunt 行性転移に分け, 転移の機序につき検討老加 えた.

\section{II 症例}

神経膠属の神経管外転移を剖検により確認できた症例 は11例であり，い-゙れも以下に述べる Weiss ${ }^{20} の$ minimal criteria を萭たしている。すなわち，1)腫瘍組 織が 中枢神経系原㹸腫瑄の組織学的特徽を示すこと, 2)臨 症状はこの中枢神経系腫瘍の徴候で発症するこ上，3) 全 身解剖がなされ，他の原発性腫瘍の存在が否定できるこ と，4) 中枢神経采腫湯と遠隔転移巣の組織像法 anaplasia の程度の差はあってあ基本的にまったく同一である ことの叫条件でる。

11 剖検例のう亏血行性転移例は 5 例，脳牢腹腔吻合術 による shunt 行性転移例は 2 例，リンパ行性転移例は 4 例である。転移経路別に症例言記述する。

血行性転移 (Table 1): 腫瘍の組織型別では, medulloblastoma 2 例, glioblastoma, anaplastic astrocytoma, cpendymoblastoma 各 1 例である. 症例 4 O medulloblastoma 例除いて全例原発腫痬の部分摘出ないし広 沉摘出術が施行されている。 また症例 $3 ， 4 ， 5$ は这室腹
腔吻合術が施行されている。全例に照射療法が行われ， medulloblastoma, cpendymoblastoma 例では替髄にむ $3,000 \sim 4,000 \mathrm{rads}$ の照射大加えてある、術後 $2 \sim 23$ 力 月で死亡し，症例 $1 ， 3$ ては主に原発腫瘍上䯣膜播 種に

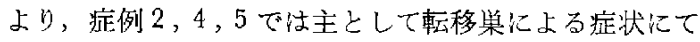
死亡した，主な転移部位としては肝 4 例，骨 3 例，肺 2 例なとである。症例 $3^{183}, 4 ， 5^{19}$ についてはすでに報告 してあるので症例 $1 ， 2$ について述心゙る。

症例 $1: 22$ 才, 女性. 全身倦意感, 頭痛, 嘔気, 嶇吐 を主訴に入院，神経学的に anosmia，両側らっ血乳頭， 左眼視力低下を認めた．左頸動脈撮影几て左前頭葉腫痬 々診断し，開頭した，原瘍は左前頭葉下面に主座在有 し，鵎卵大で，重全摘出したが前頭蓋底硬膜に沬腫煌の

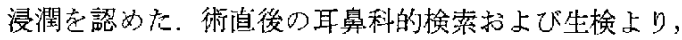
上咽頭粘膜下に浸潤増殖した腫瘍注頭盖内腫瘍の連続性 が若えりれた。術後全頭部に $3,650 \mathrm{rads}$, 左前頭部に 1,000 rads, さらに上咽頭 ・鼻腔に 5,000 rads, 脊㖪に 4,000 rads 照射を行い㑡院した. 7 力月後再発症状にて 前頭部に4, $950 \mathrm{rads}$ 上咽頭に4,800 rads 照射を行った. 街後 1 年 5 力月の時点で両側肺野にX-P 上挴指頭大に いたる腫愓陰影を認めた，全経過 2 作 1 力月，術後 1 年 11 力月で死亡した。剖検を行らと左前頭菜は境界不鮮明 な残存腫煌が認められた（Fig．1)，媨重量 $1.450 \mathrm{~g}$ ．肺 江雨側性に粟粒大から大豆大にいたる多数の灰白色結節 が散在していた．肝にも同様の小結節を 2 個認めた。組 織学的に原発腫瑏注絸胞密度が高く，類円形核定有する 


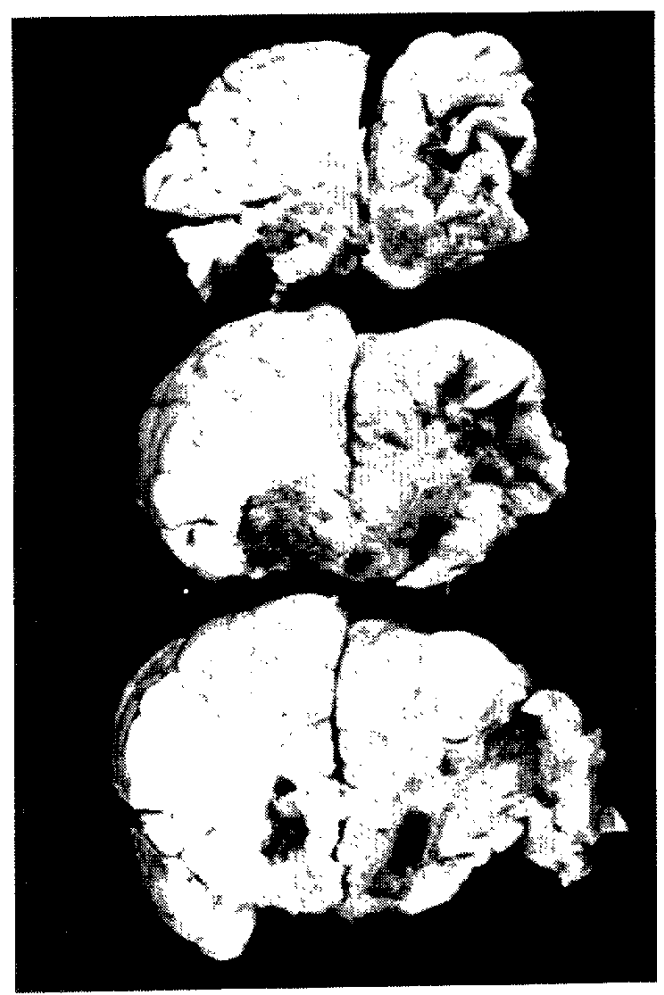

Fig. 1 Case 1, Frontal lobe tumor extending along the anterior skull base.

carrot-shaped $の$ 細胞からなり，多数の ependymal rosetteがみられ, ependymoblastoma と診断した(Fig. 2a). 肺 (Fig. 2b)，肝 (Fig. 2c) の転移巣む同様の組織少ら なり，転移巣であることが確諗された。

症例 2 : 33才, 女性. 頭痛衣主訴に入院. 神経学的に 5 っ血乳頭, 左同名性半盲を認めた。右側頭葉腫場の㟝 断のもとに開頭し，右側頭葉皮質下に主座を有する鵎卵 大董瘍を広範切除した．組織学的に腫瘍は双極性の細胞 質㔖起在有する spongioblastoma 様の部と星形グリアの 異型的細胞の增殖加らなる anaplastic astrocytoma (Fig. 4a)であった，術後病坚部に5,000 rads の照射を行い退 院した. 1 力月後全身僚意感を訴え来院, 血液生化学検 查で GOT 134, GPT 109, LDH 2,340，r-GPT 692 と いずれも高值を示し，肝炎が疑われた，その後意識障 害, 出血傾向が加わり, 全経過 15 力月, 術後 3 力月で死 亡した，剖㛟老行らと右側頭葉は広範な欠損と軟化橲死 性の部がみられ，頭頂葉，後頭葉に腫县浸潤を認めた

(脳重量 $1,370 \mathrm{~g}$ ). 肝には拇指頭大にいたる多数の灰白 色腫瘤がびまん性に認るられた（Fig．3). 肝重量 1,240 g. また検索を行った第10，12胸椎，左大腿骨㵦にも腫
瘍浸潤索認めた。肝の多発性腫瘍は異型的 astrocyteの増 殖からなり，sinusoidに沿って浸潤している．肺実質の リンパ管内や血管内に腫瘍塞栓が認められる (Fig. 4b). 肺門部りンパ節，上記骨髄にも同様の腫瘍細胞浸潤を諗 め，転移栄であることを確認した。

骾液内諉導術に上る shunt 行性転移(Table 2) : Shunt 行性転移はいずれる脳室腹腔吻合術によるもので，いず れも腹膜に着床した pattern をとっていた，原発腫瘍は 橋 glioblastoma（症例 6 ），第四脂室 ependymoblastoma (症例 7) 各 1 例で，いずれも小奣例である，両怔例と

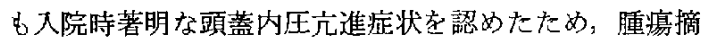
出術に先だって，または同時に脳宝腹腔吻合術が施行さ れた。症例 6 は shunt 術後 3 力月で広範な蹎膜播種の症 状により，また症例 7 は腹腔転移の症状に上り死亡し

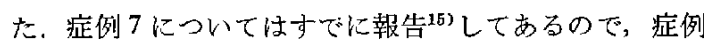
6 につき略述する。

症列 6：8才，女览，頭痛，嘔気，嘔吐を主訴に入 院. 入院時, 意識は somnolence, 両側らっ血乳頭, 右三 攴神経障害, 右外転神経麻瘴, 右顏面神释麻疩, 左上下 肢不全麻㾝の交代性片麻焷を示した，直らに媨室腹腔吻 合衔が施行され，その後のCT scan, 椎骨動脈撮影など の補助椮查法と併世，脑幹加ら右小脳橋角部に及ぶ腫演

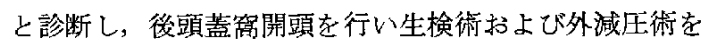
施行した。組織学的に注 medulloblastoma が疑われた。 術後全頭部に2, $950 \mathrm{rads}$, 後頭蓋窩に2,400 rads, 春㱬照

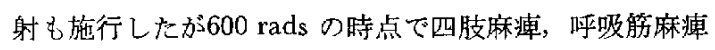
が進行し, 意識障害も加力り, 全経過 5 力月, 術後 3 力 月で死亡した．剖検を行うと腫瘍は橋腹外側に限局性， 大豆大の大きさで存在し，这底部々モ膜に播種性転移が みられ，春㔠道は全長にわたり厚い腫瘍組織で被われてい た，腹腔には少量の腹水が存在し，小骨盤腔の腹腔管先 端付近の腹膜に 2 個の径約 $1.2 \mathrm{~cm}$ の小転移栄が諮かられ た. 傍大動脈リンパ節は小豆大に腫大を示するのがみら れた，その他の諸臓器に転移は明らかでなかった。組織 学的に橋腫瘍は小型の紡鍾形細胞が密に増殖し, 多核, 巨核紐胞が混在して認められる(Fig. 5a).クモ膜に浸 潤増殖する部では胞体の乏しい小型細胞が密に増殖する 部が多い.最終的には主に小型細胞からなるglioblastoma と診断した，腹膜転移栄組織（Fig. 5b)，傍大動脈リン 八゙節組織はいずれも原発腫瘍組織と同一の形態を示し, 脳腫瘍からの転移であることを確認した。

リンパ行性転移（Table 3)：リンパ行性転移を生じた 4 例は組織型別で

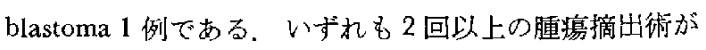
なされ，骨弁怔除去され，術後照射を受讨ている．初回 


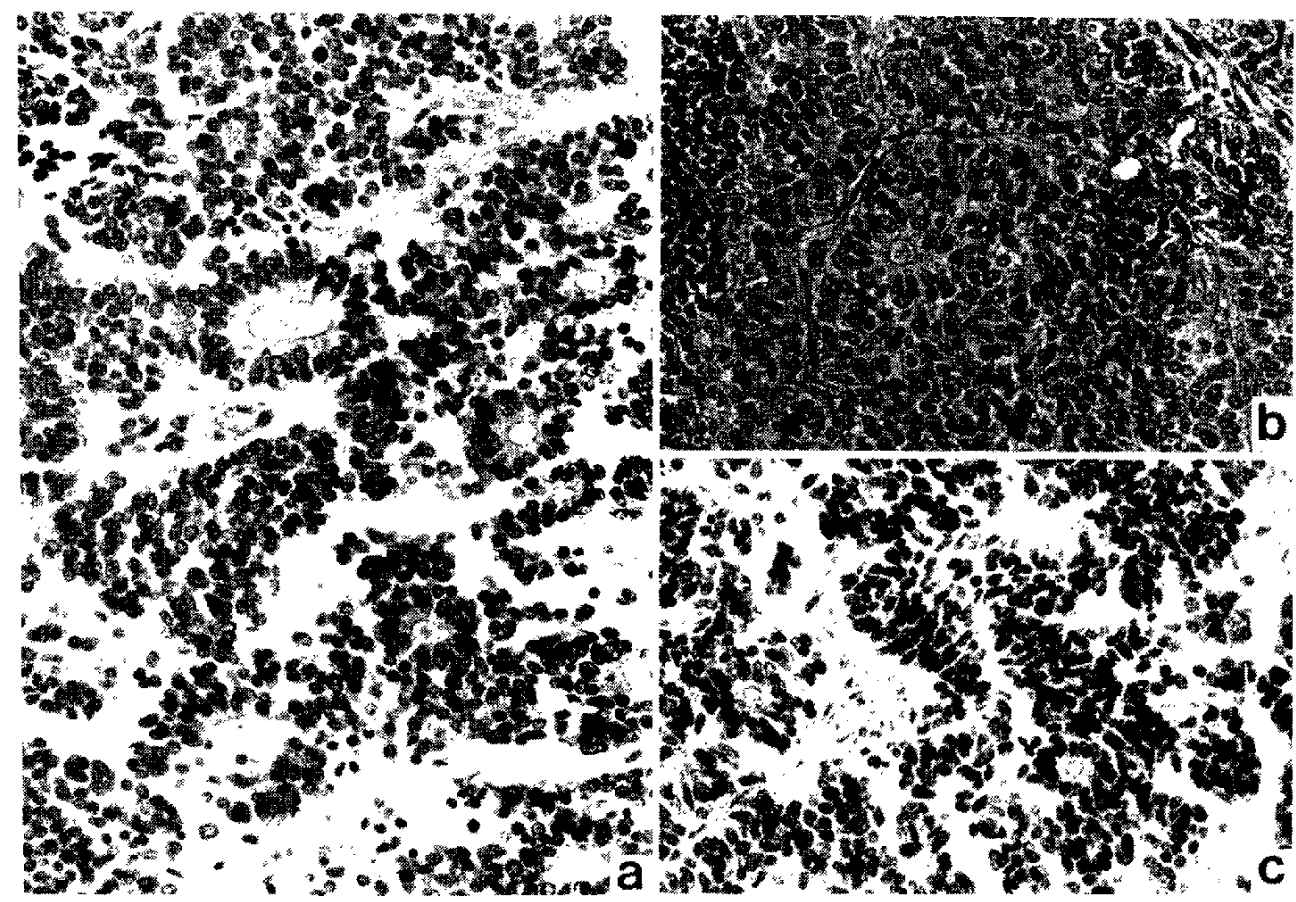

Fig. 2 Case 1. a: Ependymoblastoma of the frontal lobe. Dense cellulality and ependymal rosetles with central lumen.

b: Metastatic cpcndynoblastoma in lung.

c: Metastatic ependymoblastoma in liver.

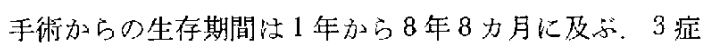
例流骨并除去部の手術創部皮下に脸腫瘍加らの連続性腫 瑒浸潤を認めた。いずれも患側の耳下腺部㔚よび项部り ンパ節に転移を生ずるのが特徴である，症例11はすでに 報告17してあるので，症例 $8,9,10$ について略述する。

症例 8 : 30才, 男性. 意識消失発作, 頭痛を主訴に入 院. 入院時, somnolence, 瞳孔不何 (右>左), 雨側ら一

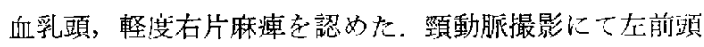
葉腫瘍之診断し，左前頭葉皮質下に主座在有する婳痬在 互全摘し，骨并は除去したままとした。術後 $\mathrm{Co}^{60} 6,000$ rads 照射し, 退院した。 3 年 5 力月後, 再発症状にて再 度左前頭葉の鷄嘼大腫瘍を摘出し, LinacX 線4,000 rads 照射戞行った. 2 回目朠瘍摘出 9 力月後, 左耳下腺部》 ンパ節が $1.5 \times 1.5 \mathrm{~cm}$ に腫大しているのに気付いた。さ らに6 力月後左前額部皮卜腫瘤, 頸部リンパ節も腫大老 示した，患者は cachexia となり，初回手術後 5 年で死亡 した，剖検を行うと左前頭葉法出血，壊死性の腫湯が存 在し(脳重量 $1,420 \mathrm{~g}$ ), 左前额部皮卜腫瘤は左前顗葉腄 瘍と連繶性が認められた。左耳下腺部扔よび钼部リンパ 節は捍指頭大から鶏卵大に腫大していた（Fig. 6)。艺
他のリンパ節，諸蹈器檕移は認められなかった。初回摘 出腫淿組織江異型的 astrocyte の増殖からなり，核分裂 像, 出血や堎死組織の混在がみられ, anaplastic astrocytoma と診断した。 2 回日手術时，剖検将組織も壊死組 織の籁䎴が应いほか同様の組織像で, meningeal disseminationを示した (Fig. 7a).耳下腺部および頸部リンパ 節転移も同一の組織像を示した (Fig. 7b).

泟例 9：4才，男肾，右頚頂葉腫瘍の診断で，腫瘍の 部分摘出㧍よび6,000 rads の照射が行われた. 7 力後 再発し，右側頭葉から巾頭蓋窝硬膜に浸潤寸る腫笏の部 分摘出，骨卉除去が施行され，3,000 rads の照射が行わ 机た。 2 回目術後 2 力月，右耳下腺部リンパ節腫大に気 付き，除々に拇指頭大に膨隆した。初回手術より1年で 死亡した，剖検を行うと譄腫瘍は右側頭・頭頂・後頭葉

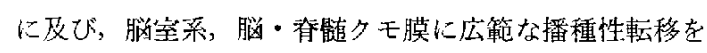
伴っていた（脳重量 $1,680 \mathrm{~g}$ )。手術創部皮下には脳腫瘍 加的連続性の腫瘍組織索認めた。右耳下腺部りンパ節, 頸部リンパ節は拇指頭大にいたる踽大を認めた。組織学 的に䍁腫瘍は glioblastoma で, 右耳下腺部拉よび頙部り ンバ節も glioblastoma の転移であった。 
Table 2 Extraneural metastases of gliomas through ventriculoperitoneal shunt

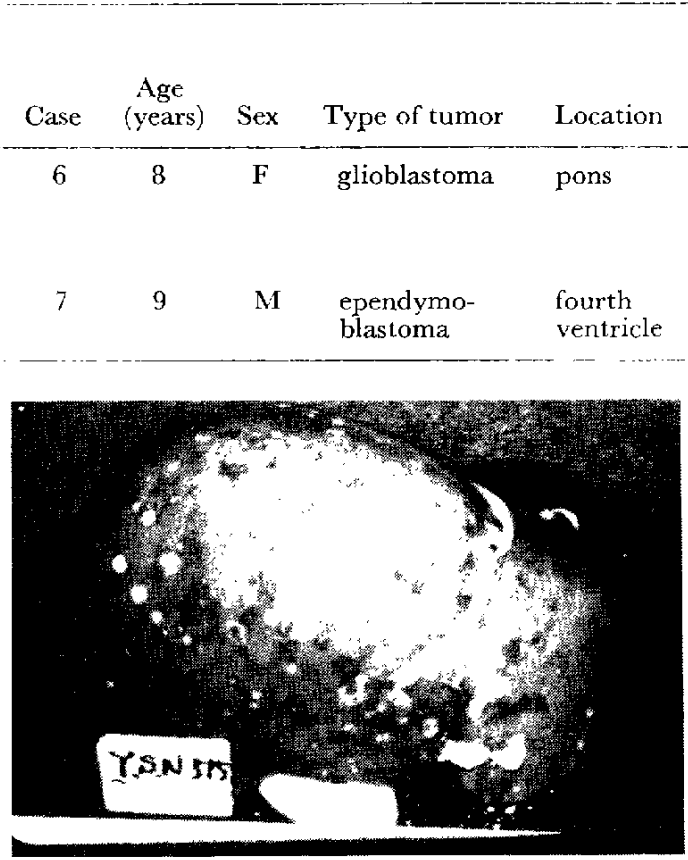

Fig. 3 Case 2. Liver showing milliary metastases of anaplastic astrocytoma.

症例10：8才，女児. 左侧頭葉腫瘍が摘除され，5,050 rads 照射とその後 2 年間 Futraful $600 \mathrm{mg} /$ 日が投与され た. 10 才時再発の診断のも上左佧頭・頭頂部腫瘍が部分 摘出され，骨弁除去による外減压術，5,000 rads 㟲射が 行われた。 11才時麻瘏の增強がみられ，CT scanにより 腫瘍の脳室壁播種, 脳宾掂大を認め, 脳室腹腔吻合術お よび全脳照射 $2,000 \mathrm{rads}$ を行った。 2 力月後左耳下腺部 および頸部りンパ節の拇指頭大䤚大を認め, 生検により 脑腫瘍の車移が题われ，同部に2, $600 \mathrm{rads}$ の照射を行っ た. その後消化管出血を合併し, 初回手術上り 3 年10力 月の経過で死亡した，剖栓を行うと左側頭・頭頂部に出 血, 壊死を伴う腫瑒が存在し, 左中頭蓋底の硬膜に浸潤

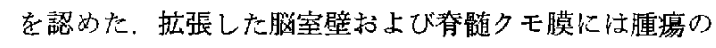
播種が顕著であった，左耳下腺部リンパ節，颚部リンパ 節は提指頭大に腫大していた。 その他のリンパ節や諸贜 器に䎐移を思わせる所見は存在しなかった. 組織学的に 成腫演は anaplastic astrocytoma であり,耳下腺部括よ び頚部りンパ節も同一の組織像を示し，脳腫瘍の転移で あることを確認した。

\section{II 考察}

\section{Glioma の神経管外血行性転移の検討}

Post-

shunting

survival Distant

(months) metastases

$1 \quad$ Linac X-ray

$2 \quad$ Linac X-ray

9,100 rads

22

peritoneum, mesenteric \& aortic lymph nodes

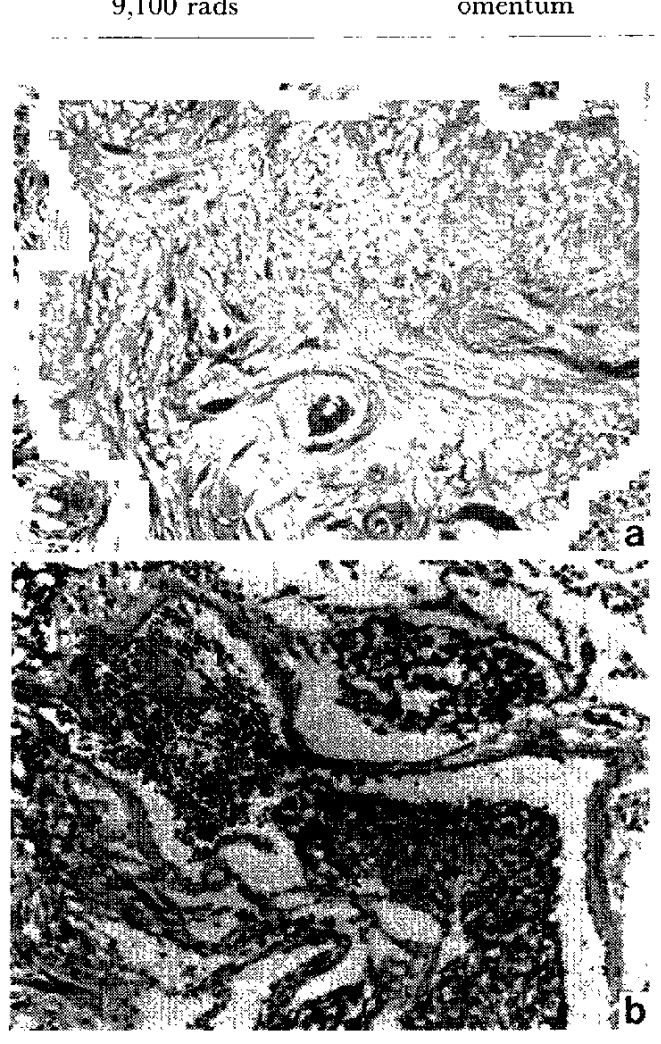

Fig. 4 Case 2. a: Anaplastic astrocytoma in the right temporal lobe.

b: Tumor emboli of anaplastic astrocytoma are scen in a pulmonary vessel and in a lymphatic vessel.

Glioma の血行性転移は骨，肝，肺などに 生ずること が多くこれまでに glioblastoma, medulloblastoma, ependymoma, oligodendroglioma 例での報告があ $3^{588)}$ 14)16)18). 我々の症例に抒いても ependymoblastoma 1, anaplastic astrocytoma 1, glioblastoma 1 , medulloblastoma 2 例が血行性遠隔転移を来した。

Legg ${ }^{10\rangle}$ によれば glioma が血行性遠隔転移を来主ため には四段階の過程が必要である，すなわち，1)血管内人 の腫瘍細胞浸潤，2)流血中で腫痬細胞が生存すること， 
Table 3 Extraneural metastases of gliomas by lymphgeneous spread

\begin{tabular}{|c|c|c|c|c|c|c|c|c|}
\hline Case & $\begin{array}{l}\text { Age } \\
\text { (years) }\end{array}$ & Sex & Type of tumor & Location & Operation & $\begin{array}{l}\text { Irradiation } \\
\text { (chemotherapy) }\end{array}$ & $\begin{array}{l}\text { Post-op. } \\
\text { survival } \\
\text { (months) }\end{array}$ & $\begin{array}{l}\text { Distant } \\
\text { mctastases }\end{array}$ \\
\hline 8 & 30 & $\mathbf{M}$ & $\begin{array}{l}\text { anaplastic } \\
\text { astrocytoma }\end{array}$ & 1. frontal & 2 & $\begin{array}{c}\mathrm{Co}^{60} 6,000 \mathrm{rads} \\
\text { Linac X-ray } \\
4,000 \mathrm{rads}\end{array}$ & 60 & $\begin{array}{l}\text { parotid \& } \\
\text { cervical } \\
\text { lymph nodes }\end{array}$ \\
\hline 9 & 4 & M & glioblastoma & r. parietal & 2 & $\begin{array}{l}\text { Linac X-ray } \\
6,000 \text { rads }\end{array}$ & 12 & $\begin{array}{l}\text { parotid \& } \\
\text { cervical } \\
\text { lymph nodes }\end{array}$ \\
\hline 10 & 8 & $\mathrm{~F}$ & $\begin{array}{l}\text { anaplastic } \\
\text { astrocytoma }\end{array}$ & l. temporal & 2 & $\begin{array}{l}\text { Linac X-ray } \\
12,050 \text { rads }\end{array}$ & 46 & $\begin{array}{l}\text { parotid \& } \\
\text { cervical } \\
\text { lymph nodes }\end{array}$ \\
\hline 11 & 11 & M & $\begin{array}{l}\text { anaplastic } \\
\text { astrocy toma }\end{array}$ & r. frontal & 3 & $\begin{array}{l}\mathrm{Co}^{60} \\
13,500 \mathrm{rads}\end{array}$ & 104 & $\begin{array}{l}\text { parotid, cerv., } \\
\text { mediastinal \& } \\
\text { paratracheal } \\
\text { lymph nodes } \\
\text { lung \& bone }\end{array}$ \\
\hline
\end{tabular}

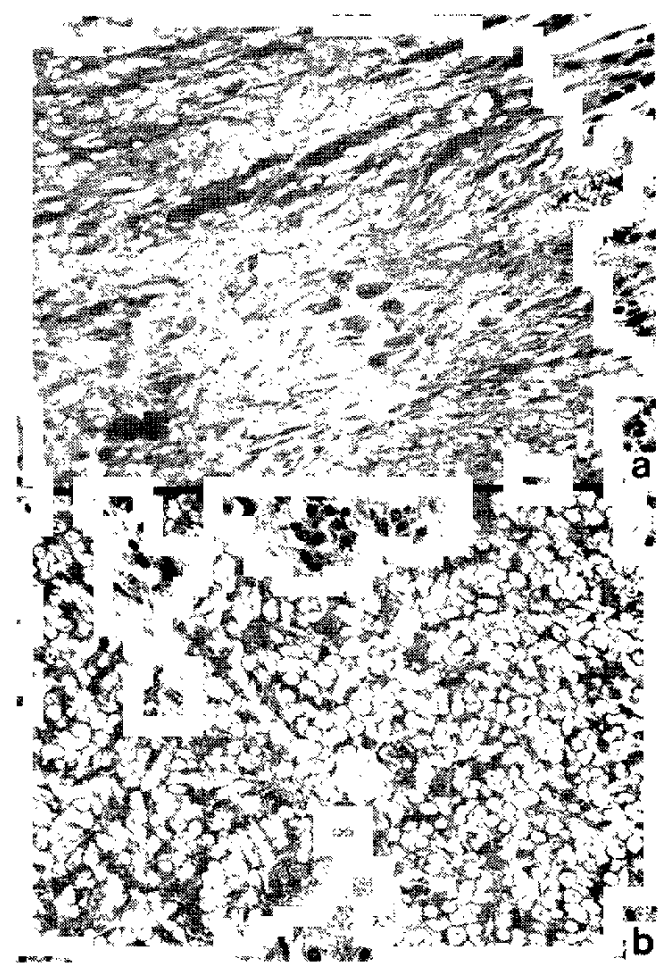

Fig. 5 Case 6. a: Glioblastoma of pons.

b: Peritoneal deposit of glioblastoma via a ventriculoperitoneal shunt.

3)腫場細胞が他の組織に侵入すること，4)新しい組織で 腫煌細胞が増殖することである。しかしながらこれらの 段階で免疫作用の生ずる可能性があり，gliomaの血行性 遠隔転移が生じにくいの忙そのためであるらと説明して いる。

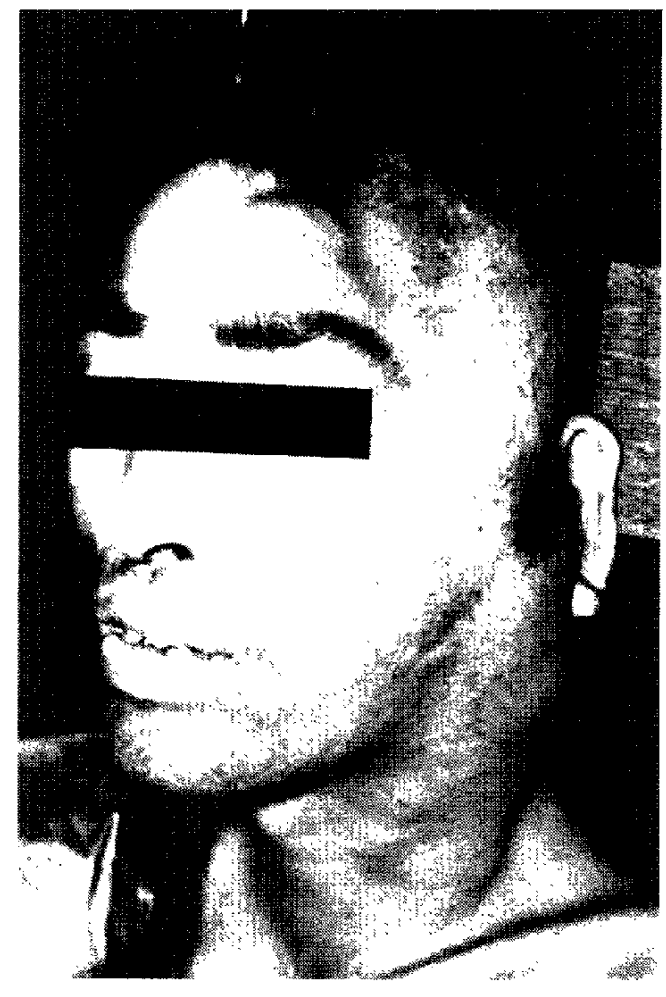

Fig. 6 Case 8. Massive cxtracranial encroachment growth and lymphogeneous metastases to cervical lymph nodes from the left frontal anaplastic astrocytoma.

慆の静脈系に関しては，加つてWillis ${ }^{21}$ 法硬膜静脈注 緻密な硬膜組織に囲されて打り，小静脈柱壁が薄く，腫 癔の進展に先んじて虚脱状態となり，い寸゙れも容易に腫 痛浸潤を受けないるのと考えた。しかしながら Anzi1 


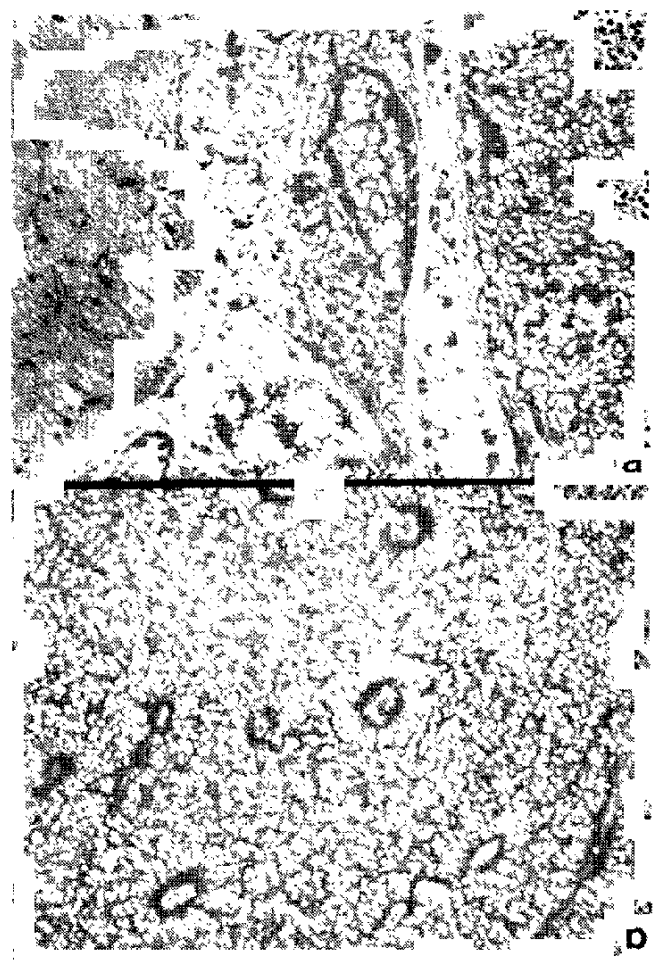

Fig. 7 Case 8. a: Frontal meningeal dissemination of anaplastic astrocytoma.

b: Metastatic anaplastic astrocytoma to the cervical lymph nodes.

が glioblastoma $の$ 非手衡例で硬膜の小静脈一の腫瘍浸 潤を热めた例や，glioblastoma や astrocytomaで腫場内 の血管壁八腫禓細胞浸潤变電顕的に認めた Kung らのの 研究に示すごとく，gliomaの血管内浸潤は明らかと確認 されてきている．本シリーズ中でる症例 $4^{199}$ は腫瘍内血 管に腫瘍細胞浸潤が認められ，また症例 1 ，症例 $5^{193}$

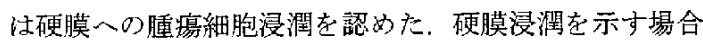
は硬膜静脈一も腫㾴細胞浸潤が起こり5ると考えられ， 手術中に腫瘍の硬膜浸潤が明らかな場合隹行性遠隔転 移の可能性を考えて対処する必要があるら。

転移部位での腫瘍組織が強い増殖性を示し，死因に直 接関倸すると思加る場合と，転移单は小さく，それに よる症状もなく，剖検時偶然発見されるものとがある。 同し肝転移にしても症例 2，4 注前者に相当し，症例 1 ， 3 䚾後者に相当すると考えられる。しかしながら転移单 の数や大きさは必ずしも術後の生存期間とは相関がみら れず,ここでも先疫作用の関与を考えさせる。

\section{2. 觬腹内誘導術による shunt 行性転移の検討}

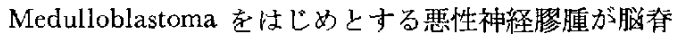

䯠液を介して中枢神経系に粗膜播種を生ずることはよく

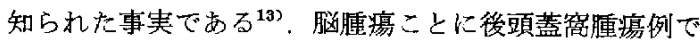
は，頭蓋内圧亢進を解除する目的で行われる髄液内誘導 術は晕液と共に腫瘍細胞を頭盍外に誘導して artificial implantation 可能にした。しかしながら㵦液内誘導術 が頻繁に行われているにもかかわらず, shunt 行性転 移

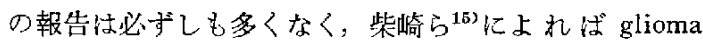
の shunt 行性転移は自験例を含め14例にすぎず，その後 Hoffman $ら^{6)} の 4$ 症 (例, Russell \& Rubinstein ${ }^{13)} の 1$ 例，本シリーズを加六20例余りと思加れる。内誘導術の 種類として $な$ ventriculoperitoneal shunt 9 例, lumboperitoneal shunt $I$ 例, ventriculopleural shunt 4 例, ventriculocaval shunt 6 例が主なところである. Hoffman らの゙によれば41例の medulloblastoma で ventriculoperitoneal shunt 行い，4例に腹腔内転移を認めた。他方 Raimondi ら ${ }^{11}$ は小児 medulloblastoma 51例中，術前お よび経過中に35例の ventriculoperitoneal shunt 老行って いるが shunt 行性転移仕 1 例むなく, shunt 手術のなき れなかった 3 例に神経管外転移起認めている。

Shunt 行性転移が生ずる条件としては，1）睡瘍が噵液 腔に露出して㧍り，2）髄液中に腫瘍細胞が遊離でき， ventricularまたは leptomeningeal dissemination を生 し，3）腹腔などの頭蓋外組織に腫瘍細胞が着休し，かつ 増殖することなどが必須であるう。多数の shunt 手術症 例のわりには glioma $の$ shunt 行性転移の頻度が少ない の怯，腹膜に腫瘍細胞が着床し，增殖するのが因難であ ることを物語っているものと考穴られる。

我么の 2 症例はいずれも脳底部壬膜から脊髄クモ膜 にかけて著しい腫瘍の dissemination 起認めた。症例 7 は初回手術㧍よび ventriculoperitoneal shunt 後 13 力月後

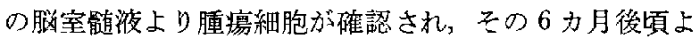
り腹水が認められ，穿刺により血性腹水と腫瘍細胞が証 明され， ${ }^{188} \mathrm{Au}$ colloid $39 \mathrm{mCi}$ 腹腔内注入遂行い，一時 的改善を認めたが，下腹部に腫溜を触れるよらになっ た. 症例 6 の転移栄は腹腔管先端部の小骨盤腔腹膜に小 転移紧 2 個を剖検洔偶然認めたものである。したがって 恶性 glioma D shunt 術施行例の剖检に際しては注意深 く腹腔内を検寀する必要があり，それによって今後 subclinical O腹腔内転移がより多く発見される可能性が あると考える。ちなみに Hoffman ら”の症例では，4 症例中腹部腫瘤と腹水の合併 1 例, 腫瘤のみ 1 例, 腹水 1 例であった。

\section{3.リンパ行性転移の検討}

リンパ行性軽移は我々の4 症例に示されたごとく, 手 術に際し骨弁除去がなされ，腫瘍が頭蓋外一向かって膨 
隆し，連続性に頭皮下軟部組織に腫塯を形成しているこ とが多い，頭皮下に浸潤した腫瘍は耳下腺部りンパ節，頸 部リンパ節を主とした転移巣索形成する，Rubinstein ${ }^{122}$ も神経管外転移が気付かれる時点では檤腫滨が骨弁除去 部の外侧に著しく堌殖していることを指摘しており，リ ンバ行性のみならず血行性遠隔転移の経路としても骨弁 除去部の腫㾇浸潤に注目している。また手術時頭皮に腫 踢の implantation を生じ，同部に増殖した腫湟がリン パ行性に広かることを指摘する報告をあるか222. Braun ら $の$ glioma 例を報告し，らち 1 例は耳下腺部リンパ節転 移を生じたと述へている。さらに腫瘍方硬膜，頭蓋骨の 脆弱な部に浸潤発育し，リンパ系に侵入することも考え られる ${ }^{22}$. Dolman ${ }^{43}$ は左耳下腺部リンパ節転移を初発 症状とした左前頭菜 glioblastoma 例䘮報告し，腫瘍の硬 膜浸潤により spontancous metastasis た、いずれにしてもりンパ行性転移はまず患側の耳下腺 部リンパ節，次いで頸部りンパ節に転移を形成寸る，頭 頸部以外の遠隔リンパ節転移を来すことは稀で，その場 合沙血行性ないし shunt 行性に他臟器に転移を形成した 後, 所属リンパ節転移孛来寸こと荐えられる、リンパ 行性転移形成までの期間性一般に血行性, shunt 行性転 移に比べて長い，我々の症例では術後 5 力月で転移を認 めた glioblastoma 例もあるが，他任初回手術から３年 7 力月, 4 年11力月, 7 年 7 力月と長い経過の後, 転移柴 に気付かれた。

症例10，1102症例で耳下腺部杍よび䕱部リンパ節転 移に対して外照射が試みられており，一時的に腫瘍の縮 少俱向が認如られた。

\section{IV まとめ}

1. 悪性神経膠腫の神経管外転移11剖検例につき, 血 行性, shunt 行性, リンパ行性転移に分類し, 転移の機 序につき梌討した。

2. 血行性転移は原発腫崵の硬膜浸潤や盾場内血管浸 潤に上り生し，骨，肝，肺などに転移寸る。

3. Shunt 行性転移は原発腫瘍が髄膜播種を伴少場合 に生ずる可能性があり， subclinical な小転移巣形成にる 注日寸ると，今後より多く発見される可能性がある。

4. yン八行性転移は遅発性で，䯚弁除去例に㕲以 て，患侧の耳下腺部リンパ節，䜖部リンパ節化初斯の車 移を形成する。

本論文の要旨は第38同日本譄神経外科学会総会 $(1979$

年，東京）に打いて発表した。

\section{文献}

1) Anzil, A. P.: Glioblastoma with extracranial metastases in the abscence of previous craniectomy. $J$ Neurosurg 33: 88 94, 1970

2) Brander, W. L. \& Turner, D. R.: Extracranial metastases from a glioma in the abscence of surgical intervention. $J$ Neurol Neurosurg Psychiatry 38: 1133-1335, 1975

3) Braun, W. \& Tzonos, T.: Zur Frage der Extrakraniealen "Metastasierung" von Gliomen durch Implantation. Acta Neurochir 19: 149-162, 1968

4) Dolman, C. L.: Lymph node metastasis as first manifestation of glioblastoma. II Neurosurg $41: 607-609,1974$

5) Glausauer, F. E. \& YuAn, R. H.: Intractanial tumors with extracranial metastases. $J$ Neurosurg 20: 474493,1963

6) Hoffman, H. J., Hendrick, E. B. \& Humphreys, R. P.: Metastasis via ventriculoperitoneal shunt in patients with medulloblastoma. $J$ Neurosurg 44 : 562-566, 1976

7) Kessler, L. A., Dugan, P. \& Concannon, J. P.: Systemic metastases of medulloblastoma promoted by shunting. Surg Neurol 3: 147-152, 1975

8) Kretschmer, H.: Die extrakranielle Metastasierung intrakranieller Geschwülste. Zbl Neurochir 35: 81-112, 1974

9) Kung, P. C., Lee, J. C. \& Bakay, L.: Vascular invasion by glioma cell in man: An electron microscopic study. J Neurosurg 31: 339-345, 1969

10) LegG, N. J.: Glioma immunology. pp 449460, In Rose, F. C. (ed): Clinical Neuroimmunology, Blackwell Scientific Publications, Oxford, 1979

11) Raimondi, A. J. \& Tomita, T.: Medulloblastoma in childhood. Comparative results of partial and total resection. Childs Brain 5: 310 328,1979

12) Rubinstein, L. J.: "Tumors of the Central Nervous System". pp 7-17, In: Atlas of Tumor Pathology, Series 2, Fascicle 6. Washington DC: Armed Forces Institute of Pathology, 1972

13) Russsell, D. S. \& Rubinstein, L. J.: "Pathology of Tumours of the Nervous System", 4th ed., Edward Arnold Ltd, 1977, $331 \mathrm{p}$

14) Schuster, H., Jellinger, K., Gund, A. \& REGEL, H.: Extracranial metastases of anaplastic cerebral gliomas. Acta Neurochir 35: 247-259, 1976

15）柴崎 尚, 武田文和, 川淵純一, 鈴木 豊, 楖沢昭吾：隠室腹腔吻合管孝経由した悪性㜆腫 瘍の神释管外転移，2剖検例の報告 おうび文献 
的考察。脳外 $5: 71-79,1977$

16) Sмith, D. R., Hardman, J. M. \& Earle, K. M.: Metastasizing neurocctodermal tumors of the central nervous system. $J$ Neurosurg 31 : 50-58, 1969

17) 武田文和, 半田一郎, 相羽 正, 川浟純一, 深井孝治 : Malignant Glioma $の$ Extracranial Metastasis O 1 剖検例。神経進步 15：720-730, 1971

18）田村 勝, 川淵純一，若尾哲夫，熊谷紀元： 小脑 glioblastoma. 自 験例上文献的考察. Neurol Med Chir 19: 517-522, 1979
19）田村 勝，们淵純一，石田陽一，堀 貞夫， 深町 彰, 若尾哲夫: Medulloblastoma の神経 管外轻移。2 部検例上文献的考察. Neurol Med Chir $20: 257-264,1980$

20) Werss, L.: Metastasizing ependymoma of the cauda equina. Cancer 8: 161-171, 1955

21) Willis, R. A.: "The Spread of Tumours in the Human Body", Butterworth \& Co. Ltd., $1952,94 \mathrm{p}$

22) Zeithofer, J. \& Kraus, H.: Über die Extrakranielle Metastasierung der Gliome. Zbl Neurochir 6: 347-357, 1952 